\title{
Sceny wspólnej uwagi w nauce czytania wspomaganej komputerowo
}

\section{Joint attentional frames in computer assisted teaching of reading}

\author{
Konrad Juszczyk \\ Instytut Językoznawstwa, Uniwersytet im. Adama Mickiewicza \\ ul. Międzychodzka 5, 60-371 Poznań \\ Centrum Przetwarzania Mowy i Języka, Instytut Filologii Angielskiej \\ Uniwersytet im. Adama Mickiewicza, Collegium Novum \\ al. Niepodległości 4, 61-784 Poznań
}

juszczykeamu.edu.pl

\begin{abstract}
This article is to explain how computer programs can teach children to read. The childrencomputer interaction is analyzed as a joint attentional frame. It is argued that children interact with computer and avatars (life-like characters) in educational programs because they treat them like other people (media equation) and act like in a joint attentional frame. The article consists of four parts. The first part is an introduction showing a broad background of this research. The second part presents current views on language acquisition in cognitive linguistics framework which is a Tomasello's socio-pragmatic theory. The third part is an analysis of some educational programs in terms of joint attentional frame with emphasis on Colorado Literacy Tutor. The last part suggests that children do treat avatars as people because they perceive them like the self, which is a consequence of being brought up in a series of joint attentional frames.
\end{abstract}

\section{Konstruktywizm i emergentyzm w akwizycji języka}

Społeczno-poznawcza koncepcja akwizycji językowej Michaela Tomasello (2002; 2005) wywodzi się z konstruktywizmu społecznego zapoczątkowanego m.in. przez Lwa Wygotskiego (1989) i kontynuowanego przez Jerome Brunera (1964 i 2006) oraz H. Rudolpha Schaffera (2005). Konstruktywiści przyjmuja, że dziecko uczestniczy w ciagu interakcji z dorosłymi, dzięki czemu rozwija swoje zdolności poznawcze (genetyczne prawo rozwoju Wygotskiego 1989). Podstawą rozwoju u ludzi jest umiejętność utożsamiania się z innymi, których traktujemy jako „takich jak my" (termin stosowany przez Tomasello 2002). Wieloletnie badania Tomasello i jego zespołu nad procesami poznawczymi u ludzi i innych naczelnych (małp człekokształtnych: szympansów i bonobo; Tomasello i inni 2007) pokazują, że my ludzie dzielimy z innymi naczelnymi wszystkie zdolności poznawcze z wyjątkiem współintencjonalności. Zdolności poznawcze, jakie dzielimy z 
innymi naczelnymi (percepcję, pamięć, kategoryzację i poznanie fizyczno-senso-motoryczne) są lepiej wykorzystywane właśnie dzięki zdolności do utożsamiania się z innymi. Ludzka umiejętność postrzegania stanów emocjonalnych innych osób zwiększa efektywność uczenia się i jest warunkiem współtworzenia kultury. Specyficzne dla człowieka uczenie się polega na naśladowaniu aktów intencjonalnych i nazywa się uczeniem się kulturowym.

Gotowość do uczestniczenia w działaniach wymagających wspólnej intencji i wspólnej uwagi dla osiągnięcia określonego celu jest dla nas ludzi decydującym czynnikiem transmisji kulturowej. Tomasello uważa wspólintencjonalność za cechę ogólnoludzką, wrodzoną i warunkującą rozwój językowy na bazie innych wrodzonych zdolności poznawczych. Pozostałe zdolności poznawcze służą rozwijaniu wiedzy o tym, jak przetwarzać informacje w różnych modalnościach (akustycznych czy wizualnych) i obejmują także pozostałe naczelne. Zdolności te nie są więc specyficzne ani jezzykowo, ani gatunkowo. Stanowisko to jest w opozycji do natywizmu znanego z prac Chomsky'ego (1957) czy Pinkera (1994) i Hausera i innych (2002), bowiem podważa hipotezę gramatyki uniwersalnej jako wrodzonej wiedzy językowej (Tomasello 1995).

Akwizycja języka jako narzędzia komunikacji to proces o charakterze emergentnym. Wiedza językowa wyłania się w toku interakcji dziecka $\mathrm{z}$ dorosłymi, co wymaga od dziecka sporo nauki (Tomasello 2005), a od dorosłego - wsparcia. Jest to spójne $\mathrm{z}$ podejściem społecznointerakcyjnym, w ramach którego zaproponowano społeczny system wsparcia przyswajania języka (LASS-Bruner 1993; Schaffer 2005). Emergentyzm nie sprawia, że język wyłania się „sam z siebie”, lecz jest efektem internalizacji wiedzy językowej podczas dialogu dziecka z dorosłym i innymi ludźmi (Wygotski 1989).

Socjogeneza języka obok takich sprawności językowych, jak słuchanie i mówienie, obejmuje także czytanie i pisanie (Wilczyńska 1999). Współcześnie sprawności te są rozwijane zarówno w języku ojczystym, jak i obcym. Wczesna nauka czytania i pisania w dwóch językach sprzyja ogólnemu rozwojowi dziecka (Komorowska 1982) i jest koniecznym przygotowaniem do pełnego funkcjonowania w naszej kulturze. Dlatego też jest powszechna nie tylko w Polsce, lecz także w innych krajach Unii Europejskiej (Eurydice 2005). Najnowsze badania dotyczące metod nauczania czytania i pisania podkreślają udział pośrednika w wyrabianiu umiejętności czytelniczych i zalecają łączenie metod czytania globalnego i analitycznego (Marzano i Paytner 2004). Zalecenie to jest realizacją postulatów konstruktywizmu społecznego i zbiega się z koncepcją Tomasello (2002), który przyjmuje teorię podwójnego dziedziczenia w celu wyjaśnienia źródeł kultury i poznania. Kostruktywiści zakładają, że wrodzone zdolności poznawcze u ludzi są wystarczające, by w interakcji z innymi („takimi jak ja”) ludźmi rozwinąć wszystkie sprawności językowe (Bruner 2006). Kultura służy przystosowaniu ludzi do skutecznego używania swoich umysłów aby lepiej współpracować, „wytwarzać znaczenia” oraz „podtrzymywać wspólnotę interpretacyjną” (określenia Brunera 2006).

Dzisiejsza kultura edukacji obejmuje także elektroniczne narzędzia umysłowe - komputery i programy edukacyjne. Powszechność ich zastosowań na całym świecie i rozwój e-learningu świadczy o ich skuteczności jako pośredników nauczania. Próbą odpowiedzi na pytanie, dlaczego tak się dzieje jest powiązanie konstruktywizmu społecznego Tomasello, Brunera i Wygotskiego z tezą Reeves i Nassa zwaną media equation (2002). Dialog człowiek (dziecko) - komputer polega na głębokim utożsamieniu się człowieka $\mathrm{z}$ medium. Człowiek postrzega komputer jako istotę społeczną, gdyż powierza mu część swoich kompetencji poznawczych. I dzieje się tak najprawdopodobniej dlatego, że ludzie mają potrzebę utożsamiania się z tymi, z którymi wykonuja wspólnie pewne czynności, wspólnie osiagają określone cele, realizują swoje intencje. Innymi słowy, ludzie przenoszą swoje poczucie współintencjonalności z komunikacji człowiek-człowiek na komunikację człowiek-komputer. Kiedy komputerowe programy edukacyjne stają się coraz bardziej przyjazne użytkownikowi i spełniają rolę pośredników w nauczaniu (na przykład czytania), uczący się (dzieci) traktują je tak, jak innych pośredników. Niniejszy artykuł przedstawia krótką charakterystykę scen wspólnej uwagi według Tomasello, a następnie opisuje naukę czytania wspomaganą komputerowo jako scenę wspólnej uwagi. 


\section{Nabywanie języka w scenach wspólnej uwagi}

Decydującym czynnikiem transmisji kulturowej (uczenia się kulturowego) jest umiejętność utożsamiania się z innymi. Jest to cecha ogólnoludzka i prawdopodobnie wrodzona. Jednocześnie Tomasello (2002) zwraca uwagę na różny sposób przekazywania wiedzy dzieciom w poszczególnych kulturach. Edukacja może bowiem być mniej lub bardziej oparta na piśmie i innych przekaźnikach (druk, multimedia, Internet) lub przebiegać bez pomocy pisma, czyli w drodze obserwacji i naśladowania. Wszystkie wspomniane formy edukacji wywodzą się jednak z dialogu i bazują na tej samej umiejętności utożsamiania się z innymi.

\subsection{Warunki nabywania języka}

Nabywanie języka wymaga, by dziecko (Tomasello 2002:144):

$>$ rozumiało innych jako sprawców intencjonalnych;

$>$ uczestniczyło w scenach wspólnej uwagi, które stanowią społeczno-poznawczą podstawę aktów symbolicznej - w tym także językowej - komunikacji;

> rozumiało nie tylko zwykłe intencje, ale także intencje komunikacyjne, polegające na tym, że ktoś chce, by dziecko zwróciło uwagę na jakiś element sceny wspólnej uwagi;

$>$ umiało zamienić się rolami z dorosłym w procesie kulturowego uczenia się i w ten sposób umiało posłużyć się symbolami, jakimi posłużono się wobec niego.

Akwizycja języka jest procesem, w którym powstają symbole oparte na intersubiektywnie rozumianej konwencji.

\subsection{Predyspozycje dzieci do nabycia języka}

Dzieci są przygotowane do nabycia języka dzięki licznym zdolnościom społeczno-poznawczym, które Tomasello $(2002 ; 2005)$ dzieli na dwie grupy: wyszukiwanie wzorców (pattern finding) i rozpoznawanie intencji (intention reading).

\subsubsection{Wyszukiwanie wzorców}

Pierwsza grupa zdolności obejmuje działania poznawcze, czyli przetwarzanie informacji i kategoryzację, a składa się z następujących umiejętności (Tomasello 2005:4):

$>$ formowanie kategorii percepcyjnych i konceptualnych $\mathrm{z}$ obiektów $\mathrm{i}$ wydarzeń wykazujących podobieństwo;

$>$ formowanie schematów sensomotorycznych na podstawie powtarzających się wzorców percepcji i działania;

$>$ przeprowadzanie statystycznej analizy dystrybucyjnej na różnego rodzaju sekwencjach percepcyjnych i zachowaniowych (behawioralnych);

$>$ tworzenie analogii (odwzorowania strukturalne) pomiędzy dwiema bardziej złożonymi całościami, na podstawie podobnych funkcji pewnych elementów tych całości.

Zdolność wyszukiwania wzorców polega na rozpoznawaniu powtarzających się konstrukcji językowych w potoku słyszanej mowy. Dzieci zaczynają wybierać spośród słyszanych wypowiedzi określone powtarzające się wzorce językowe jeszcze zanim skończą pierwszy rok życia. Umiejętność wyszukiwania wzorców nie dotyczy tylko języka, gdyż udowodniono, że dzieci równie dobrze wyszukują wzorce $\mathrm{w}$ sekwencjach bodźców wizualnych. Co więcej, zdolność wyszukiwania wzorców występuje także u innych naczelnych. Zdolności te nie są więc specyficzne ani językowo, ani gatunkowo. Samo odnajdywanie wzorców, ustalanie granic jednostek językowych i reguł ich występowania w sekwencjach nie wystarcza do posługiwania się językiem.

\subsubsection{Rozpoznawanie intencji}

Dzieci zaczynają postrzegać innych ludzi jako osoby intencjonalne, już w wieku około jednego roku. Stopniowo przekonują się, że ludzie działają celowo i pod wpływem innych. Dzieci stają się mistrzami w czytaniu umysłów (Tomasello 2007), co pozwala im na pełny rozwój komunikacyjny. 
Rozpoznawanie intencji innych ludzi jest podstawą dla rozumienia sensu symboli językowych, które kierują wspólną uwagą uczestników interakcji symbolicznej. To, co jest przedmiotem wspólnej uwagi, staje się znaczeniem symbolu językowego.

Szczegółowy zestaw zdolności związanych z rozpoznawaniem intencji zawiera (Tomasello 2005):

$>$ dzielenie z innymi osobami uwagi skierowanej na określony przedmiot czy zdarzenie, którym się interesują;

$>$ podążanie za uwagą i gestami wskazywania innych osób na oddalone przedmioty i zdarzenia, które są poza aktualnie bliską interakcją;

$>$ kierowanie uwagi innych osób na oddalone przedmioty za pomoca gestów wskazywania (pointing), pokazywania i używania innych niejęzykowych gestów;

$>$ uczenie się kulturowe (przez naśladowanie) działań intencjonalnych innych osób, a w szczególności działań komunikacyjnych motywowanych intencją komunikacyjna.

Podstawową jednostką językową jest symbol, czyli konwencjonalne (co nie oznacza zupełnej niezależności czy arbitralności) połączenie formy i znaczenia. Tomasello zakłada, że typowe dla ludzi procesy myślenia i posługiwanie się językiem opierają się na zawierających perspektywę symbolach. Nauka ich używania wymaga kilkuletniego treningu w interakcjach z dorosłymi, dzięki którym dziecko przekonuje się o heurystycznej funkcji dialogu. Działalność poznawcza człowieka opiera się zatem na dialogu, którego uczestnicy za pomocą powtarzanych zachowań (wzorców) okazują określone intencje i modelują swoje zachowania.

\subsubsection{Uwaga a symbol i język}

Skonwencjonalizowane zachowania stają się symbolami językowymi i pozwalają na „intersubiektywne konstruowanie świata na miliony sposobów, które zostały zebrane przez daną kulturę w czasie historycznym". (Tomasello 2002:130). Dzieci w procesie nabywania języka internalizują te sposoby (symbole i ich reprezentacje) w trakcie kolejnych interakcji społecznych $\mathrm{z}$ dorosłymi. Konwencja jest zatem ustanawiana na drodze powtarzających się scen wspólnej uwagi, podczas których ustala się przedmiot wspólnej uwagi będący znaczeniem i używa się określonych form dźwiękowych, aby wskazać na ów przedmiot. Odniesienie językowe według Tomasello to „akt społeczny, który polega na tym, że jedna osoba próbuje skłonić drugą osobę do skupienia uwagi na czymś w świecie zewnętrznym" (Tomasello 2002:132). Najważniejszą funkcją języka jest więc kierowanie uwagą rozmówców i ustalanie przedmiotu wspólnej uwagi.

Ludzie uczestnicząc $\mathrm{w}$ interakcjach ustalają wspólne spojrzenie na wybrane fragmenty rzeczywistości i przypisują im określone zachowania (gesty i słowa). Zachowania zyskuja odpowiednie reprezentacje symboliczne, które są intersubiektywne (,podzielane społecznie”; Tomasello 2002:130) i zawierają perspektywę, czego najlepszym przykładem są różnego rodzaju kategoryzacje rzeczywistości za pomocą symboli.

\subsection{Sceny wspólnej uwagi}

Wyliczone powyżej zdolności pozwalają dzieciom na współtworzenie scen wspólnej uwagi (SWU), w których rozpoznają cudze, a z czasem realizują swoje intencje komunikacyjne, oraz uczą się przez naśladowanie z odwróceniem ról. Tomasello definiuje sceny wspólnej uwagi jako:

„Interakcje społeczne, w których przez pewien czas dorosły i dziecko razem zwracają uwagę na jakiś przedmiot oraz na to, że partner w interakcji zwraca uwagę na ten przedmiot" (Tomasello 2002:132).

SWU mają więc naturę triadyczną, czyli składają się z trzech elementów: dziecka, dorosłego i przedmiotu wspólnej uwagi (np. zabawki). Uczestnicy podzielają wspólną uwagę i cel interakcji. Przedmiotem wspólnej uwagi dla uczestników SWU jest wyłącznie ten przedmiot, na który zwracają uwagę, mimo świadomości istnienia pozostałych. Innymi słowy, dla uczestników SWU istotny jest przedmiot będący $\mathrm{w}$ centrum ich uwagi, a pozostałe mogą zostać wskazane i przywołane za pomocą spojrzenia, gestu wskazującego i wreszcie symbolu językowego. Tomasello podkreśla, że „zarówno dorosły, jak i dziecko muszą wiedzieć, że ich uwaga jest skupiona właśnie 
na tych przedmiotach" (Tomasello 2002:132). Samo skupianie uwagi uczestników interakcji na tym samym przedmiocie nie wystarcza do wytworzenia sceny wspólnej uwagi. Nie może bowiem zabraknąć u nich wzajemnej świadomości na czym skupiają uwagę.

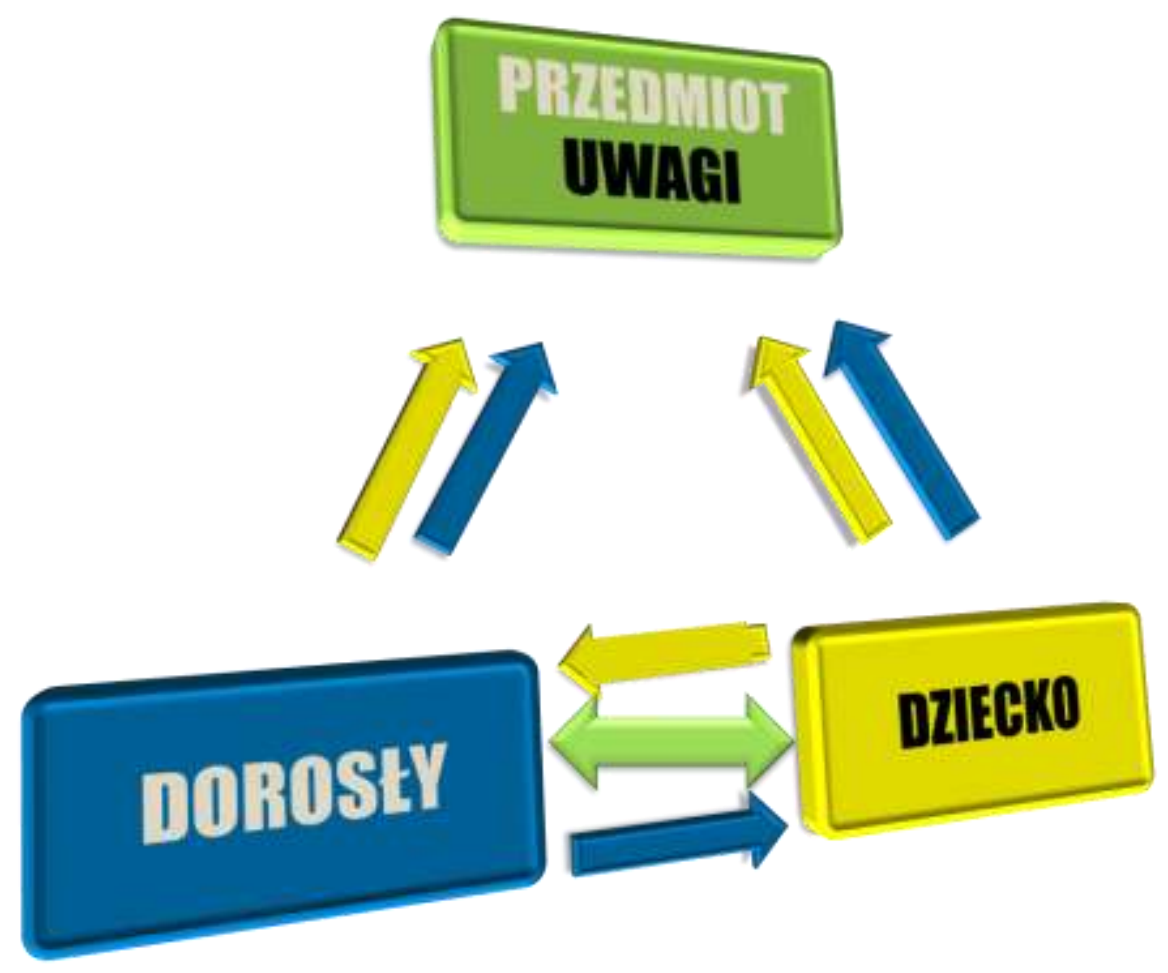

\section{Rys. 1 Triadyczna relacja $w$ scenie wspólnej uwagi ${ }^{l}$}

Powyższy rysunek przedstawia SWU: prostokąty obrazują trzy elementy SWU, a strzałki relacje pomiędzy nimi. Kolory strzałek są zgodne kolorami prostokątów, aby podkreślić, że DOROSŁY kieruje uwagę na przedmiot uwagi i na dziecko wraz z jego stanem uwagowym. Tak samo czyni DZIECKO, które odwołuje się do przedmiotu uwagi poprzez DOROSŁEGO. Zielona strzałka pomiędzy DOROSŁYM a DZIECKIEM jest dwustronna, gdyż uczestnicy interakcji są świadomi swoich przedmiotów uwagi. Warunkiem zaistnienia SWU jest uzgodnienie wspólnego przedmiotu uwagi w celu realizacji wspólnego celu i intencji. Innymi słowy, sceną wspólnej uwagi dla dziecka i dorosłego jest to, „,co razem robimy”. Jest to ściśle określona w czasie i przestrzeni działalność, której razem poświęcają uwagę i względem której wzajemnie dostrajają się (por. Fogel i Garvey 2007).

\subsection{Intencja komunikacyjna}

Zdolność do rozumienia innych osób jako istot intencjonalnych pojawia się u ludzkich dzieci już między 9 a 12 miesiącem życia. Dzieci uzyskują tę zdolność w trakcie kolejnych interakcji z ludźmi. Najczęściej są to rodzice i rodzeństwo lub inni opiekunowie. To właśnie ich gesty i słowa są kojarzone $\mathrm{z}$ kontekstem i stopniowo interpretowane przez dzieci jako zachowania komunikacyjne. Dla zrozumienia sensu danego gestu lub słowa potrzebne jest założenie, że każdy z nich jest motywowany przez określoną intencję komunikacyjną. Dzieci przekonują się o tym dzięki obserwacji przebiegu działań komunikacyjnych dorosłych, a w szczególności dzięki zauważanym skutkom tych działań oraz dzięki uczestnictwu $\mathrm{w}$ nich. To właśnie uczestnictwo dzieci w interakcjach prowadzi je do postrzegania ,innych ludzi jako istot intencjonalnych, oraz z

\footnotetext{
${ }^{1}$ Rysunek wykonano na podstawie schematów Tomasello (2002; 2005; 2007).
} 
ich rozumienia i postrzegania siebie samych jako intencjonalnych uczestników scen wspólnej uwagi" (Tomasello 2002:139).

Ludzie używają języka, by wyrazić określone intencje ku komunikacji, czyli chęci zwrócenia czyjejśs uwagi na własny stan uwagi. Tomasello proponuje szczególne ujęcie intencji komunikacyjnej jako „rozumienia intencji drugiej osoby względem stanu mojej uwagi” (Tomasello 2002:139). Kiedy dorosły wskazuje dziecku na zabawkę przez nazwanie jej słowem (lalka), zabawka znajduje się w centrum wspólnej uwagi uczestników interakcji, a intencją dorosłego jest chęć, by dziecko zwróciło uwagę na tę właśnie zabawkę. Rozpoznawanie intencji komunikacyjnej jest niezbędne dla rozwoju języka jako narzędzia komunikacji. Dzięki niej dzieci rozumieją, dlaczego ludzie posługują się takimi, a nie innymi jednostkami językowymi w określonych sytuacjach.

„Sounds become language for young children when and only they understand that the adult is making that sound with the intention that they attend to something." (Tomasello 2005:23).

Dzieci najpierw obserwuja, jak dorosły za pomocą zabawki, czy innego przedmiotu, zwraca ich uwagę na ten przedmiot. Wówczas dzieci monitorują stan intencjonalny dorosłego względem zabawki. Następnie obserwują dorosłego, który za pomocą tej samej zabawki wyraża intencję komunikacyjną skierowaną do dziecka. Wtedy zaczynają monitorować własne stany intencjonalne oraz stan intencjonalny dorosłego względem własnych stanów intencjonalnych. Jednym z pierwszych i najważniejszych zauważanych przez dzieci wskaźników kierowania uwagi u dorosłych jest spojrzenie. W momencie osiagnięcia drugiego roku życia dzieci potrafią już zaobserwować kierunek spojrzenia u dorosłego i na tej podstawie ustalają jego przedmiot uwagi oraz intencję komunikacyjną.

\subsection{Naśladowanie z zamianą ról}

Dzieci nabywają zdolności aktywnego używania symboli językowych w momencie gdy odkrywają możliwość odwrócenia ról w interakcji symbolicznej. Możliwość ta stanowi najważniejszy proces uczenia się kulturowego. Kolejne spotkania z innymi ludźmi (najczęściej w formie zabaw) są dla dzieci okazją, by zrozumieć, że ,ja wobec niego mogę zrobić to samo, co on właśnie zrobił wobec mnie" (Tomasello 2002:130).

Według Tomasello rozumienie intencji dorosłych przez dzieci „wywodzi się z powtarzania tej samej czynności ogólnej w regularny czy rutynowy sposób, tak że dziecko może określić jej strukturę i sposób funkcjonowania różnorodnych ról społecznych wewnątrz niej (Tomasello 2002:147)". Dziecko rozumie SWU przez swoje uczestnictwo w niej oraz przez swoją rolę w interakcji. Uczestnicząc $w$ scenie wspólnej uwagi obserwuje ją niejako z góry i widzi zamienność ról uczestników interakcji symbolicznej. To pozwala mu na przyjęcie roli dorosłego i posłużenie się nowym słowem (wypowiedzią), aby zwrócić uwagę dorosłego w tę samą stronę, w którą przedtem dorosły zwrócił uwagę dziecka. Jest to proces uczenia się kulturowego, a dokładniej uczenie się przez naśladowanie. Celem działania intencjonalnego dziecka nie jest jego uwaga, lecz stan uwagi dorosłego.

Tomasello przyjmuje za Wygotskim (1989), że używanie symboli językowych w wypowiedziach podczas dialogu podlega internalizacji. Reprezentacja poznawcza symbolu jest nie tylko intersubiektywna, lecz zawiera także perspektywę. Dziecko, czyli najmłodszy użytkownik języka, zyskuje świadomość, że język służy wzajemnej kontroli wspólnej uwagi uczestników interakcji symbolicznej. Różnie dobierane symbole w danej scenie mogą wskazywać na różne aspekty wskazywanej rzeczy, czyli wpływać na podzielaną uwagę. Tomasello bowiem traktuje symbole i konstrukcje językowe jako symbole zawierające perspektywę. Rodzice przekazuja je dziecku w celu nakłaniania innych do przyjmowania pewnej perspektywy wobec jakiegoś zjawiska (por. Tomasello 2002:202).

Podsumowując, sceny wspólnej uwagi są interakcją społeczno-symboliczną, w której dzieci uczą się używania symboli językowych. Nauka w SWU polega na rozpoznawaniu intencji komunikacyjnych i naśladowaniu $\mathrm{z}$ odwróceniem ról. Jednostki językowe są symboliczne, skonwencjonalizowane i zawierają perspektywę. Język w świetle teorii Tomasello spełnia funkcję regulacyjną i służy do kierowania wspólną uwagą rozmówców. 
Opis interakcji symbolicznej jako scen wspólnej uwagi wywodzi się z koncepcji epizodu wspólnej uwagi, której wprowadzenie można przypisywać Brunerowi i jego współpracownikom oraz Schafferowi (2005). Tomasello podkreśla jednak, że scenę i epizod wspólnej uwagi odróżniają dwie cechy: po pierwsze SWU nie są ani zdarzeniami percepcyjnymi, ani językowymi, bo „rozgrywają się na gruncie pośrednim, gruncie społecznie podzielanej rzeczywistości, pomiędzy bardziej rozległym światem percepcyjnym, a węższym światem językowym" (Tomasello 2002:133); po drugie dziecko pojmuje SWU przez świadomość uczestnictwa w niej i rozumienia swojej roli w interakcji. Innymi słowy, Tomasello akcentuje wspólintencjonalność i świadomość wzajemnego skupiania wspólnej uwagi na pewnym przedmiocie u uczestników dialogu. Wspólne jest założenie wywodzące się z psychologii Wygotskiego (1989), że dziecko podczas nauki z pomocą dorosłego poprzez dialog internalizuje jego perspektywę, czyli „rozumie instrukcje dorosłego (symuluje działania regulujące dorosłego) w odniesieniu do swojego własnego rozumienia sytuacji, co wymaga koordynacji obu perspektyw" (Tomasello 2002:257). Instrukcje dorosłego są przez Brunera (1980:503) określane jako rusztowanie (scaffolding). Kilkuletnie dzieci potrafią także stosować różne techniki samoregulacji, do których zalicza się samoobserwację, strategie metapoznawcze i werbalizację (Tomasello 2002:256). Za werbalizację jako technikę samoregulacji uznaje się mowę wewnętrzną i egocentryczną dziecka. Dzieci głośno komentują wykonywane przez siebie i innych czynności, dzięki czemu internalizują zewnętrzną mowę społeczną do wewnętrznej mowy indywidualnej (Wygotski 1989).

\section{Wirtualne sceny wspólnej uwagi}

Mając scharakteryzowaną koncepcję nabywania języka według Tomasello możemy spojrzeć na nauczanie czytania wspomagane komputerowo jako na scenę wspólnej uwagi. Poniższy rysunek pokazuje SWU, w której rolę DOROSŁEGO przejmuje AWATAR, czyli komputerowa symulacja nauczyciela. Zanim przejdziemy do prezentacji programów do nauczania czytania, warto wyjaśnić, czym jest awatar.
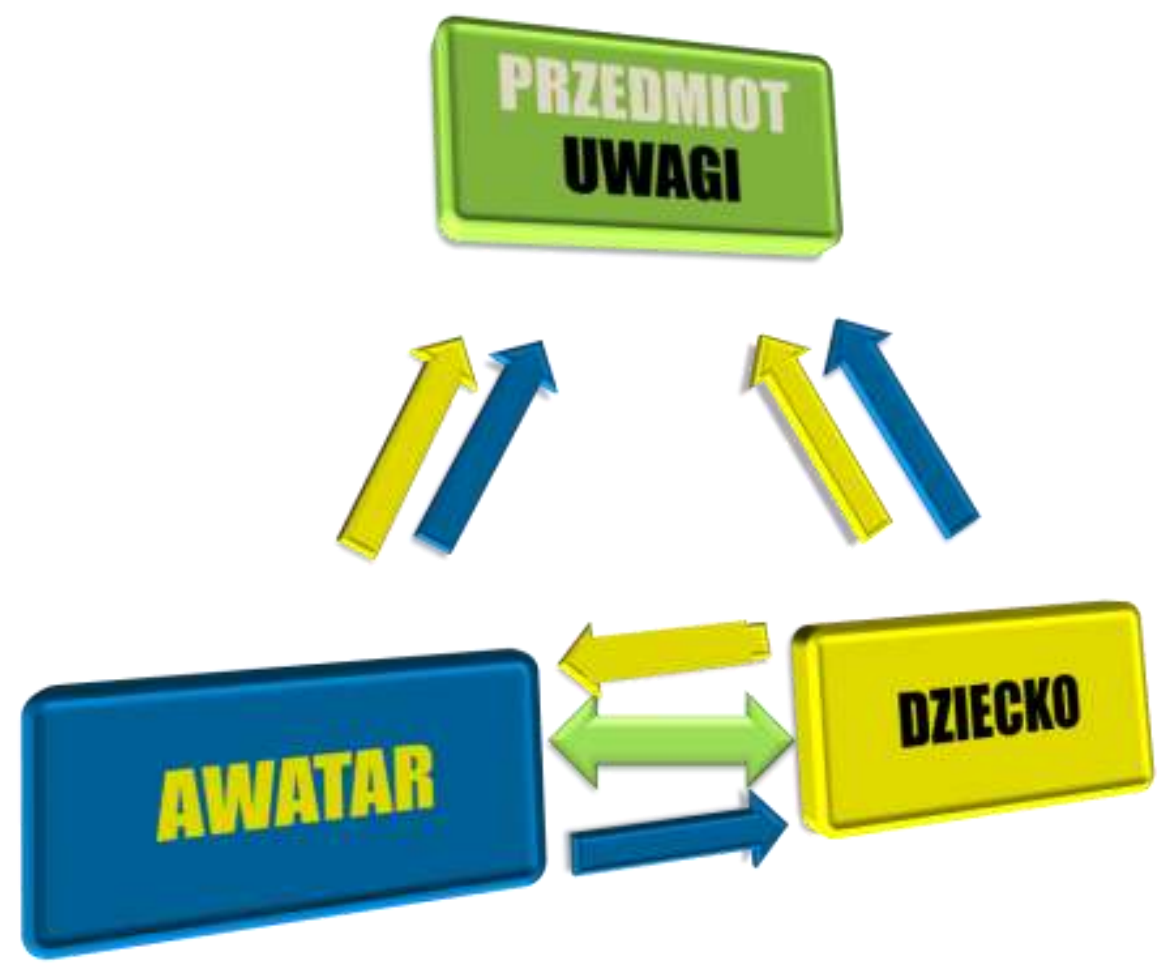

Rys. 2 Triadyczna relacja $w$ scenie wspólnej uwagi z awatarem $w$ roli dorostego 
Przegląd najnowszych form komunikacji człowiek-komputer wskazuje na humanizację mediów, czyli dostosowywanie ich do zachowań ludzi. Programy komputerowe symulują zachowania społeczne, dzięki czemu ich użytkownik czuje się „przy nich” tak, jak przy ludziach. Najlepiej świadczą o tym komunikaty skierowane do użytkownika, które coraz częściej przyjmują formę grzecznych zwrotów i pytań w drugiej osobie. Wystarczy zwrócić uwagę na cztery przykłady:

$>$ Kiedy dzwonimy na infolinię firmy, banku lub sklepu, słyszymy głos automatycznej telefonistki: Witamy w (...); jeśli chcesz połaczyć się z (...) wybierz cyfrę (...).

$>$ Jeśli korzystamy z systemów automatycznej nawigacji (GPS) słyszymy miły i ciepły głos, który mówi: Za dwieście metrów skręć w prawo!

$>$ Ilekroć podejmujemy pieniądze z bankomatu spoglądamy na ekran minikomputera, na którym wyświetla się zapytanie: Czy potrzebujesz więcej czasu? Odbierz kartę i gotówkę.

$>$ Gdy poszukujemy informacji w Internecie za pomocą wyszukiwarki, chcemy kupić bilet lub przejrzeć ofertę sklepu, spotykamy animowaną postać kobiety lub mężczyzny, który mówi: $W$ czym mogę ci pomóc? Zadaj mi pytanie.

Przykłady można mnożyć, bowiem z pomocy różnego rodzaju komputerów korzystamy równie często jak z pomocy ludzi. Komputery zastępują ludzi w roli telefonistek czy konsultantek, a także „kasjerów” (bankomat, czyli ATM - Automatic Teller Machine, wyręcza osobę wypłacającą pieniądze w okienku bankowym). Systemy automatycznej nawigacji (GPS) wyznaczają kierowcom optymalną trasę i prowadzą ich krok po kroku, dzięki czemu nie muszą oni spoglądać na mapę. Co ciekawe, jeśli podczas jazdy pomiędzy kierowcą a pasażerami toczą się jakieś rozmowy, to nawigacja głosowa najczęściej je przerywa. Rozmowy ustają, gdyż rozmówcy wiedza, że kierowca chce usłyszeć jaką trasę zaproponuje GPS i dlatego dopuszczają GPS do głosu. Funkcjonowanie systemów automatycznej nawigacji pokazuje, jak komputer (medium) może sterować uwagą ludzi. Zwroty adresowane do użytkownika są bardziej motywujące i skłaniają do działania, bo wpływają na jego stany uwagowe tak, jak komunikaty innych ludzi. Podobnie instruktaż $w$ programach edukacyjnych dla dzieci jest tym bardziej skuteczny, im bardziej zwrócony do ucznia. Wykorzystany w tym celu głos ma przypominać głos nauczycielki lub nauczyciela, dlatego instrukcje są nagrywane przez lektorów, a nie wytwarzane za pomoca syntezy mowy. W nowoczesnych programach edukacyjnych stosuje się także awatary, czyli animowane postacie, które mają naśladować człowieka. Awatary występują także jako pomocnicy na stronach sklepów internetowych (np. IKEA), linii lotniczych (np. LOT), agencji ubezpieczeniowych (np. HESTIA), czy wyszukiwarek (np. DEWEY). Ich zadaniem jest wspomaganie człowieka $\mathrm{w}$ selekcji informacji, podejmowaniu decyzji i realizacji zakupów. Twórcy awatarów zakładaja, że obecność awatara na stronie, którą ogląda użytkownik, pomaga mu skupić uwagę i znaleźć informację jakiej poszukuje. Im więcej czasu spędzamy przy komputerze, który zastępuje człowieka, tym bardziej oczekujemy, że będzie to czas równie przyjemny, jak czas rozmowy z osobą. Ludzkie oczekiwania wobec mediów wynikają wprost $\mathrm{z}$ wyuczonej przez kulturę i ewolucję potrzeby kontaktu i zrozumienia wobec kogoś, komu powierzamy istotne zadania poznawcze. Potrzeba ta szczególnie wiąże się ze współintencjonalnością, której mediom czy awatarom niewątpliwie jeszcze brakuje. Jednakże kiedy powierzamy im takie zadania poznawcze, jak pomoc w podejmowaniu decyzji, czy dostępu do informacji, naturalnie nawiązujemy $\mathrm{z}$ nimi taki kontakt, jaki nawiązujemy $\mathrm{z}$ ludźmi. Zostało to potwierdzone $\mathrm{w}$ przytaczanych już badaniach Reeves i Nass, a także w pracy polskiej (Karpiński 1998). Teza o utożsamianiu mediów z ludźmi znajduje także potwierdzenie $\mathrm{w}$ badaniu interakcji dzieckokomputer w nauczaniu czytania. Analiza wybranych programów edukacyjnych przedstawiona $\mathrm{w}$ poniższym artykule ma na celu pokazanie, jak nauczanie dziecka przez komputer zbliża się do sceny wspólnej uwagi. 


\subsection{Komputerowe wspomaganie nauki czytania: Klik uczy czytać i Czytam i Pisze}

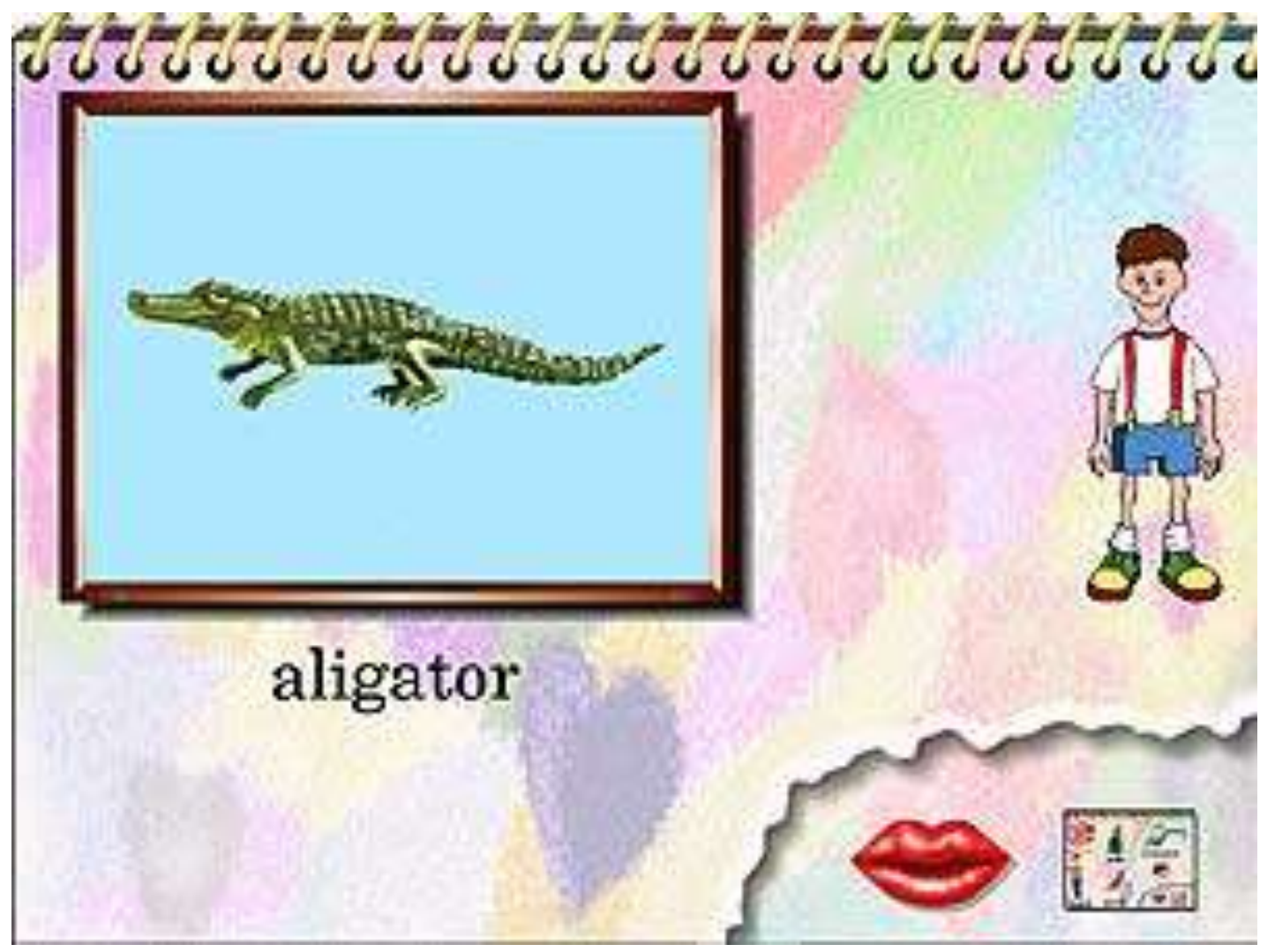

\section{Rys. 3 Plansza programu „Klik uczy czytać”}

Program KLIK uczy czytać został wydany przez Wydawnictwa Szkolne i Pedagogiczne, które opublikowały całą serię programów edukacyjnych z udziałem chłopca o imieniu KLIK. Gruba (2002) uznała w badaniach porównawczych Klik... za jedyny nowoczesny multimedialny program do nauki. Wskazała także na fakt, że program ten nie pozwala dziecku na naukę samodzielną, bez nauczyciela. Powyższy zrzut z ekranu to przykładowe ćwiczenie z udziałem Klika. Chcąc przeanalizować nauczanie w programie Klik ... jako SWU wyróżnimy następujące elementy:

$>$ przedmiot wspólnej uwagi,

$>$ awatar dorosłego (nauczyciela),

$>$ intencję komunikacyjną

$>$ naśladowanie z zamianą ról.

Przedmiotem wspólnej uwagi jest w nauka rozpoznawania i nazywania liter, a w konkretnym ćwiczeniu widocznym na obrazku - czytanie podpisów pod obrazkami itp. Awatarem nauczyciela jest chłopiec (Klik), który podaje polecenia i nagradza za wykonanie ćwiczenia, lecz milczy, gdy uczeń się myli. Chłopiec zdaje się być towarzyszem ucznia, lecz nie sprawdza się jako nauczyciel, gdyż nie daje konkretnych wskazówek (rusztowania). Przy tak ograniczonym dialogu dziecka z komputerem trudno analizować intencje komunikacyjne czy naśladowanie z zamianą ról. Brak wsparcia ze strony awatara utrudnia dziecku utrzymanie uwagi. Dlatego program jest przydatny jedynie jako pomoc w nauczaniu czytania dla logopedów i pedagogów, którzy wykorzystują go jako źródło atrakcyjnych ćwiczeń multimedialnych. 


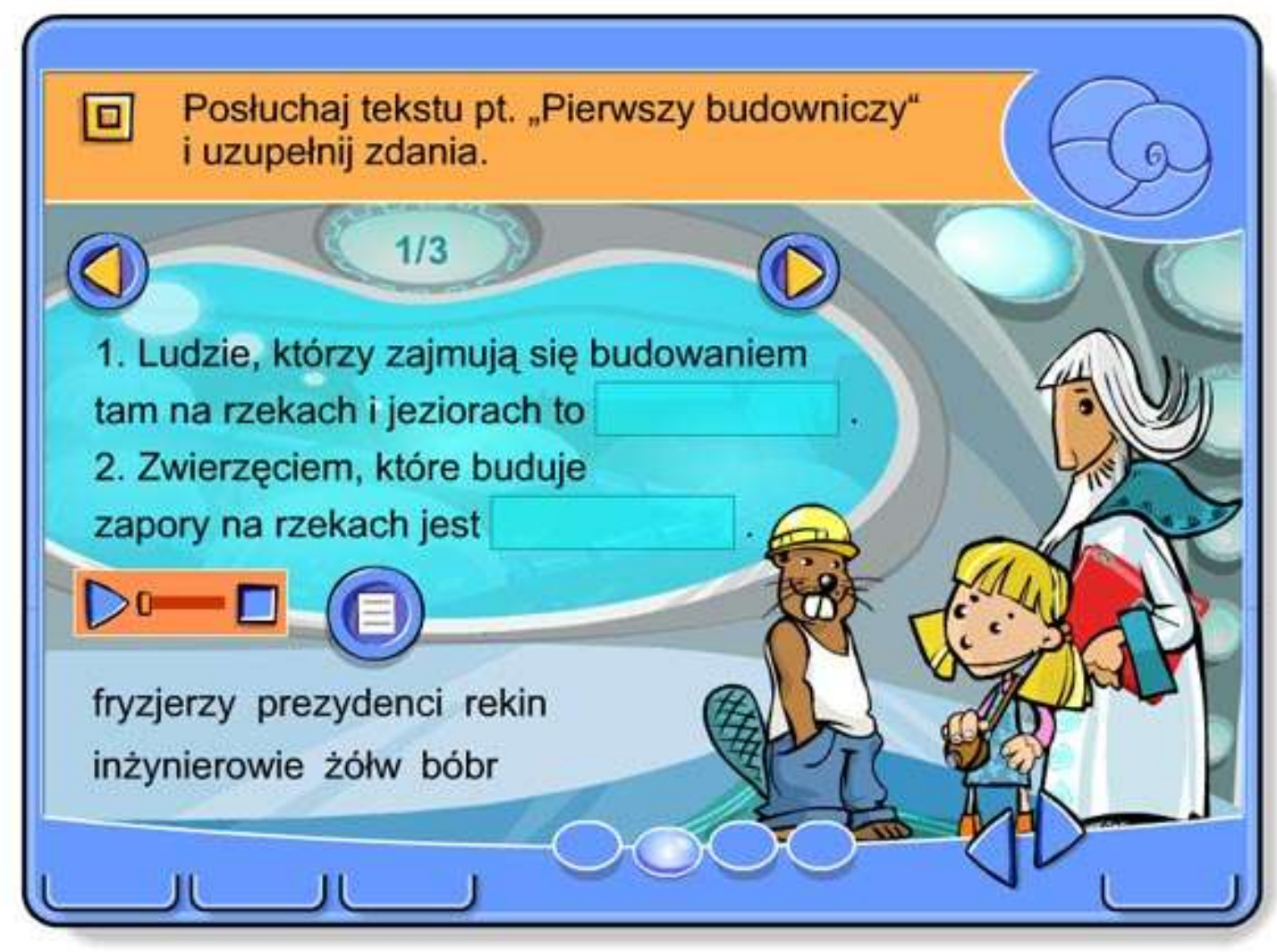

Rys. 4 Plansza programu ,Czytam i piszę”

Następny program - Czytam i pisze - powstał w polskiej firmie Young Digital Poland. Interfejs tego programu jest lepiej dopracowany pod względem graficznym, a ćwiczenia są bardziej zróżnicowane. Postacią prowadzącą uczniów przez program jest profesor Grafologus, który wprowadza ich w świat czytania i pisania. Jednak podczas ćwiczeń obecny jest tylko głos, który wydaje polecenia. Podobnie jak w poprzednim programie, awatar nie spełnia roli nauczyciela, gdyż nie wyjaśnia błędów uczniów, nie dostarcza im wsparcia (rusztowania). W przykładowym ćwiczeniu można oczywiście wyróżnić przedmiot wspólnej uwagi jako wypełnianie tekstu odpowiednimi wyrazami czytanymi „zza kadru” i widocznymi pod tekstem. Widoczne na obrazku postacie są ilustracją tekstu, a nie awatarami. Program pozostaje więc multimedialną pomocą $\mathrm{w}$ dydaktyce i służy jako uzupełnienie lekcji szkolnych lub zajęć domowych.

Programy tego typu cieszą się dużym powodzeniem i uznaniem zarówno wśród nauczycieli i rodziców, jak i samych dzieci. Nauczyciele otrzymują bardzo dobrze opracowane ćwiczenia czytania, które są oparte na konkretnych założeniach metodycznych i mają atrakcyjną formę interaktywnej zabawy. Dzieci chętnie bawią się takimi programami i traktują je jako edukacyjne gry komputerowe (por. Walencik-Topiłko 2005). Multimedialne programy edukacyjne zastępuja powoli tradycyjne elementarze, jakie w nauczaniu są stosowane już setki lat ${ }^{2}$. Wskazane $\mathrm{w}$ niniejszym artykule braki nie umniejszają wartości dydaktycznej wybranych programów. Przedstawione programy nie zapewniają dziecku takich możliwości, jakie daje scena wspólnej uwagi z dorosłym, gdyż są od niej zbyt odległe. Dlatego warto zaprezentować program, który w znaczący sposób zbliża nauczanie przez komputer do sceny wspólnej uwagi.

\footnotetext{
${ }^{2}$ Przegląd elementarzy przedstawia praca Taboła (2005), a także artykuł autora (Juszczyk 2006), gdzie porównano elementarze tradycyjne i elektroniczne.
} 


\subsection{Komputerowe wspomaganie nauki czytania: CLT jako SWU}

Colorado Literacy Tutor (CLT) to amerykański program uczący czytania w języku angielskim. Szczegółowy opis programu został już przedstawiony we wcześniejszych artykułach autora (Juszczyk 2005; 2006); w tym artykule zostaną więc wyróżnione te cechy CLT, które są zbieżne z opisaną wcześniej sceną wspólnej uwagi. Interfejs CLT różni się od pozostałych programów obecnością awatara - wirtualnej nauczycielki o imieniu Marni . Twórcy CLT - CSLR $^{3}$ przeprowadzili liczne badania i eksperymenty (Wise i inni 2000; Wise [w druku]; Cole i inni 2003), w których wykazali, że skuteczność nauczania czytania za pomocą komputera zapewniają takie czynniki, jak:

$>$ połączenie metody globalnej i analitycznej;

$>$ szczegółowy instruktaż podczas czytania książek i wykonywania ćwiczeń;

$>$ obecność awatara zwanego life-like character, który pomaga dziecku w czytaniu;

$>$ zindywidualizowany dobór ćwiczeń i przykładów o określonej trudności;

$>$ kontrola postępów uczniów i możliwość nadzorowania nauki przez nauczycieli i rodziców ${ }^{4}$.

Pierwsze dwa postulaty są zgodne ze wspomnianą już wcześniej i ogólnie przyjętą metodyką nauczania czytania zalecaną także w wielu innych publikacjach (Marzano i Paytner 2004; Gibson i Levin 1975 ), w tym także polskich (Kamińska 1999). Czytanie metodą globalną jest realizowane w CLT poprzez interaktywne ksiażeczki, a ćwiczeniu czytania metodami analitycznymi służą Foundational Reading Exercises (FRE) (Wise [w druku]). Nauczanie z udziałem pośrednika wymaga wyszkolenia nauczycieli wyspecjalizowanych $\mathrm{w}$ doskonaleniu czytania i gotowych spędzać z dziećmi wiele godzin pomagając im w ćwiczeniu tej umiejętności. W większości szkół takich specjalistów albo brakuje, albo ich rolę pełnią logopedzi i psycholodzy, dla których pomoc dzieciom mającym trudności w czytaniu jest jednym z wielu obowiązków. Program CLT został stworzony tak, by wyręczyć specjalistów w ćwiczeniu czytania, co jest spełnieniem trzeciego postulatu. Rolę pośrednika spełnia awatar, czyli animowana postać wirtualnej nauczycielki-Marni . Dzięki jej obecności dziecko ma wrażenie uczestniczenia w interakcji, która jest bardzo bliska scenie wspólnej uwagi. Twórcy CLT zaprogramowali Marni tak, by dialog dziecka z komputerem jak najbardziej przypominał komunikację „twarzą-w-twarz” (face-to-face), a nauczanie było zindywidualizowane (one-on-one tutoring). Marni naśladuje dorosłego jako uczestnika SWU dzięki takim cechom, jak:

$>$ animowana twarz Marni pokazuje reakcje emocjonalne wirtualnej nauczycielki;

> polecenia i komentarze Marni są wymawiane naturalnym, ludzkim głosem;

$>$ Marni thumaczy uczniowi, jak wykonać dane zadanie, podaje wskazówki, a także chwali ucznia lub tłumaczy jakie błędy popełnia;

$>$ głowa i oczy Marni są ruchome, co daje uczniowi wrażenie bycia obserwowanym.

\footnotetext{
${ }^{3}$ Center for Speech and Language Research: http://cslr.colorado.edu

${ }^{4}$ System kontroli przebiegu i wyników ćwiczeń w CLT Managed Learning Environment (MLE) został już omówiony (Juszczyk 2006).
} 


\section{Stew Dentone}

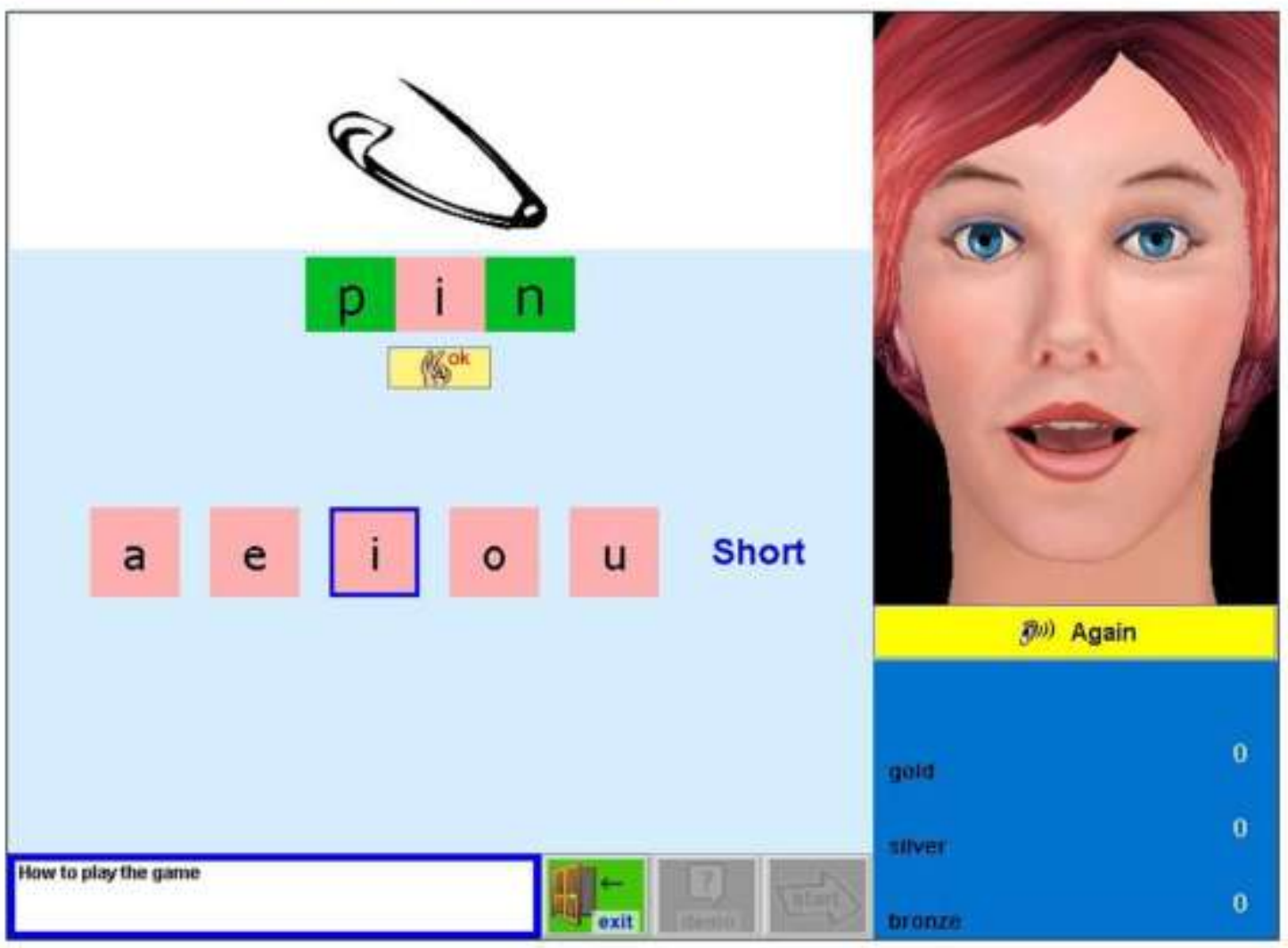

\section{Rys. 5 Interfejs programu Colorado Literacy Tutor}

Uczeń wchodzi z wirtualnq nauczycielka $\mathrm{w}$ interakcję, która przypomina mu scenę wspólnej uwagi. Przedmiotem wspólnej uwagi dla dziecka jako ucznia i Marni jako pośrednika jest konkretne ćwiczenie czytania jako zadanie do wykonania. Ekran komputera, na którym jest wyświetlane ćwiczenie czytania, jest polem ograniczającym skupianie uwagi dziecka na wykonywaniu ćwiczenia. Nic poza ekranem czy komputerem nie powinno zajmować uwagi dziecka. Ponieważ uwaga dziecka w wieku szkolnym jest rozproszona i mimowolna, dziecko wykonujące ćwiczenia wymaga kontroli i zachęcania. Wirtualna nauczycielka - Marni jest obecna na ekranie podczas każdego ćwiczenia i tym samym jest stale obecna „przy” dziecku. Marni staje się „strażniczką uwagi” dziecka, a jej obecność jest wzmocniona przez wyraźne, ruchome oczy awatara, które sprawiają wrażenie obserwujących i pilnujących ucznia. Co ważne, w przypadku dłuższej bezczynności ucznia, Marni potrafi go przywołać. Technicznie możliwe jest także, by Marni śledziła ucznia swym wzrokiem, co jeszcze bardziej pozwoliłoby utrzymać uwagę dziecka przy danym ćwiczeniu. Co więcej, planowano także, by Marni mogła zawołać swego ucznia, gdyby ten oddalił się od komputera (Wise [w druku]). W pierwszej części artykułu wspomniano, że według Tomasello (2002) najważniejszą funkcją języka jest kierowanie uwagą rozmówców i ustalanie przedmiotu wspólnej uwagi. Marni realizuje tę funkcję dzięki możliwie jak najbardziej naturalnym zachowaniom językowym i naśladowaniu człowieka.

Wszelkie starania upodobnienia wirtualnej nauczycielki - Marni do nauczycielki naturalnej, ludzkiej sprawiają także, że nauczanie czytania za pomocą komputera przybliża się do sceny wspólnej uwagi. Obserwacje i wyniki badań autora artykułu pozwalają sądzić, że dzieci robią z Marni to, co robilyby z ludzką nauczycielką. Dzieci wchodzą w interakcję z Marni, gdyż postrzegają ją jako prawdziwą nauczycielkę czytania, czyli utożsamiają medium z człowiekiem, które go przedstawia. Świadczy o tym m.in. sposób, w jaki toczy się interakcja dziecka z komputerem w programie CLT. Dziecko steruje komputerem za pomocą myszki, a rezultaty 
swoich działań widzi na ekranie. Marni komentuje słownie poczynania dziecka i tym samym steruje nim, kontroluje jego uwagę i czuwa nad przebiegiem ćwiczeń. Polecenia Marni wskazują dziecku ściśle określony cel interakcji i prowadzą do niego przez dawanie odpowiednich wskazówek. Zachowania i komunikaty wygłaszane przez Marni są uzależnione od indywidualnych zachowań ucznia. Wypowiedzi Marni można podzielić na POWITANIA, POLECENIA, PODPOWIEDZI, POCHWAŁY (POŻEGNANIA). Ćwiczenia rozpoczynają się od POWITAŃ typu:

> Welcome to the Matching Game!

$>$ I like playing this game!

$>$ Here we go!

Następnie padają POLECENIA i PODPOWIEDZI zależne od poczynań ucznia:

$>$ Find the lowercase letters that match!

$>$ Try again, they are a match;

$>$ Give it another try, they are not a match;

Poprawne odpowiedzi ucznia są nagradzane POCHWAŁAMI w rodzaju:

$>$ Well done!

$>$ Fantastic!

$>$ That's right!

POCHWAŁY są także wygłaszane po przerobieniu wszystkich przykładów; następnie Marni zaprasza ucznia do kolejnego ćwiczenia. Szegółowy opis wypowiedzi Marni podano w artykule autora (Juszczyk 2006). Tam też przeanalizowano przebieg ćwiczeń i dobór przykładów w CLT. Marni wybiera przykłady o różnym stopniu trudności dopasowując ćwiczenia do danego ucznia. Dzięki temu uczeń ma wpływ na przebieg ćwiczenia i zyskuje poczucie interakcyjności zbliżone do naturalnej sceny wspólnej uwagi.

Wypowiedzi dzieci zarejestrowane podczas testów CLT świadczą o próbach nawiązania kontaktu z Marni. Dzieci komentują przebieg ćwiczeń, zachowania Marni i swoje postępy:

$>$ Co jest? Tap, tap, no mów tap! no mów ten tap! No tap, tap, no! Masz tu swoje tap [klikając na tab] Masz tu tap;

$>$ O! A teraz rusza glowa! [Marni];

$>$ Co powiedziata? Jeszcze raz, bo nie styszatem...

$>$ Tu pomylitem, miat być czwarty [wyraz klikany na ekranie];

$>$ O, ułożylem po angielsku zdanie, ok;

Sceny wspólnej uwagi są kontekstem, w którym dzieci uczą się używania symboli językowych dzięki rozumieniu intencji komunikacyjnych i naśladowaniu z zamianą ról. W wirtualnej SWU, jaką jest na przykład CLT, dzieci mają możliwość nauczenia się czytania, czyli używania wizualnych symboli językowych, których funkcje także poznają dzięki czytaniu intencji i naśladowaniu wirtualnej nauczycielki. Dzieci chętnie i sprawnie wykonują polecenia Marni, co świadczy o tym, że poprawnie odczytują jej intencje komunikacyjne. Przytoczone wypowiedzi dzieci skierowane do Marni pokazują z kolei, że dzieci mają wyobrażenie o tym, co myśli Marni, a dokładniej - postrzegają jej wypowiedzi jako prezentację jej przekonań. Jeśli dzieci postrzegają Marni jako swoją nauczycielkę (media equation), to postrzegają także jej uwagi jako część wiedzy o swoich postępach i trudnościach w nauce czytania. Marni zwraca uwagę dziecka na konkretne błędy, jakie ono popełnia i skłania je do ich poprawy. Dzieci słuchając jej wskazówek poprawiają się, bo domyślają się, że w ten sposób wpływają na jej stan uwagowy tak, jak robią to wobec dorosłych. Kiedy Marni jest strażniczką uwagi dziecka, dziecko wykonując jej polecenia działa intencjonalnie w celu zwrócenia uwagi Marni na swoje działania. Każda reakcja Marni widoczna na ekranie (skinięcie głową, uśmiech itp.) pozwala dziecku sądzić, że jego działania są przez nią zauważane i doceniane. Komentarze Marni wzmacniają u dziecka wrażenie uczestniczenia w scenie wspólnej uwagi. Skuteczność Marni jako nauczycielki i „strażniczki uwagi” potwierdzono już w badaniach amerykańskich (Wise, Cole, Pellom) i polskich (Juszczyk 2005; 2006). Przedstawiona analiza programu CLT miała na celu pokazanie, jak nauczanie czytania wspomagane komputerem może być bliskie SWU. 


\section{Podsumowanie}

Porównanie wybranych programów do nauczania czytania wskazuje kierunek rozwoju technologii kształcenia za pomocą komputera i możliwości jej badania jako scen wspólnej uwagi. Dzieci w kontakcie $\mathrm{z}$ komputerem i awatarem wykazuja zachowania prospołeczne i komunikacyjne, bo postrzegają nauczanie wspomagane przez komputer jako wirtualną scenę wspólnej uwagi. Zarówno w naturalnej, jak i wirtualnej SWU, dzieci korzystają ze swych zdolności do rozpoznawania intencji (wymienionych wcześniej w artykule). Dzieci robią to nie dlatego, że komputer czy awatar mają intencje, lecz dlatego, że są przygotowane do takiej formy interakcji i przekonane o jej skuteczności przez wychowanie w kulturze. Funkcjonowanie wirtualnych SWU opiera się na założeniu, że dzieci postrzegają awatara jako nauczycielkę, czyli utożsamiają wirtualną nauczycielkę z prawdziwą tak, jak dorośli utożsamiają media z rzeczywistością.

Chcąc podsumować przedstawione badania można sformułować następujące tezy:

$>$ Dzieci są zaprogramowane do interakcji przez kulturę (socjalizacja), a awatary przez technologię;

$>$ Dlatego dzieci, nauczone interakcji z dorosłymi w SWU, naturalnie nawiązują dialog z awatarami tak, jak z dorosłymi (media equation).

$>\mathrm{W}$ kontakcie z mediami naczającymi powtarzają (przenoszą) swoje zachowania z SWU, bo inaczej nie potrafia;

$>$ Tak samo awatary komunikują się z dziećmi i uczą je, bo inaczej... nie potrafią;

$>$ Uczestnicy tego dialogu mogą zachowywać się „tak jak my”, gdyż pochodzą od „takich jak my".

Dzieci urodzone już w XXI wieku mają do czynienia z komputerami i innymi urządzeniami elektronicznymi równie często jak z innymi zabawkami, lecz zdarza się, że są to zupełnie inne zabawki niż te, którymi bawili się ich rodzice. Jak pokazały eksperymenty grupy badaczy w San Diego (Tanaka i inni 2007), dzieci chętnie bawią się z wykazującym zachowania społeczne robotem nazwanym QRIO. Pięć miesięcy przebywania humanoidalnego QRIO wśród dzieci sprawiło, że dzieci postrzegały go jako „takiego jak one” - przyjaznego rówieśnika. QRIO ma ponad pół metra wzrostu, chodzi na dwóch nogach, a sylwetką przypomina człowieka. Dodatkowo QRIO reaguje na dotyk, co jeszcze bardziej sprzyja socjalizacji i przywiązaniu. Autorzy badań konkludują że roboty stają się częścią naszego otoczenia, a ludzie powierzają im coraz więcej zadań. Dlatego można się spodziewać, że w niedalekiej przyszłości dzieci będą nauczane nie tylko przez awatary w programach komputerowych, lecz także przez roboty obecne w ich pokoju. 


\section{Bibliografia}

Bruner, J. 1964. Proces ksztatcenia. Warszawa: Państwowy Instytut Wydawniczy.

Bruner, J. 1980. Ontogeneza aktów mowy. w Badania nad rozwojem języka dziecka, Shugar, G. W. i Smoczyńska, M. (red.). Warszawa Państwowe Wydadnictwo Naukowe. 483-513.

Bruner, J. 1993. Child'S Talk - Learning to Use Language. New York: Norton.

Bruner, J. 2006. Kultura edukacji. Kraków: Uniwersitas.

Chomsky, N. 1957/1977. Recenzja z Verbal Behaviour B.F. Skinnera. w Lingwistyka a filozofia, Stanosz, B. (red.). Warszawa: Państwowe Wydawnictwo Naukowe.

Cole, R., i inni. 2003. Perceptive Animated Interfaces: First Steps Toward a New Paradigm for Human Computer Interaction. Proceedings of the IEEE: Special Issue on Multimodal Human Computer Interface. http://CSLR.colorado.edu/beginweb/perceptive_animated_interfaces/perceptive_animated_interfaces.html

Eurydice. 2005. Kluczowe dane dotyczące nauczania języków. http://oraprod.eurydice.org/ressources/eurydice/pdf/ countryspecificpressdos/PR049PL.pdf

Fogel, A. i Garvey, A. 2007. Alive communication. Infant Behavior \& Development, 30, 251-257.

Gibson, E., i H. Levin. 1975. The Psychology of Reading. Cambridge, Mass.: M.I.T.

Gruba, J. 2002. Komputerowe wspomaganie umiejętności czytania u dzieci sześcioletnich. Kraków: Oficyna Wydawnicza Impuls.

Hauser, M. Chomsky, N. Fitch, W. 2002. The Faculty of Language: What Is It, Who Has It, and How Did It Evolve? Science 298 (5590), 1569. (22 November 2002).

Juszczyk, K. 2005. Colorado Literacy Tutor jako pomoc w nauce i doskonaleniu czytania w języku angielskim dla polskich dzieci. Investigationes Linguisticae XII:44-61.

Juszczyk, K. 2006. Ćwiczenie czytania w języku obcym wspomagane komputerowo programem Colorado Literacy Tutor. Investigationes Linguisticae XIII:62-85.

Kamińska, K. 1999. Nauka czytania dzieci w wieku przedszkolnym. Warszawa: Wydawnictwa Szkolne i Pedagogiczne SA.

Karpiński, M. 1998. Psycholingwistyczne aspekty komunikacji człowiek-komputer. Poznań: UAM.

Komorowska, H. 1982. Metody badań empirycznych w glottodydaktyce. Warszawa: Państwowe Wydawnictwo Naukowe. Marzano, R., i D. Paynter. 2004. Trudna sztuka pisania i czytania. Gdańsk: Gdańskie Wydawnictwo Psychologiczne.

Pinker, S. 1994. The Language Instinct. London: Penguin Books.

Reeves, B., i C. Nass. 2000. Media i ludzie. Warszawa: PIW.

Schaffer, H. 2005. Psychologia dziecka. Warszawa: Wydawnictwo Naukowe PWN.

Taboł, S. 2005. Istota czytania. Kraków: Oficyna Wydawnicza Impuls.

Tanaka, F., i inni. 2007. Socialization between toddlers and robots at an early childhood education center. Proceedings of the National Academy of Sciences 104: 17954-17958.

Tomasello, M. 1995. Language is not an instinct. Cognitive Development 10:131-156.

Tomasello, M. 2002. Kulturowe źródła ludzkiego poznawania. Warszawa: Państwowy Instytut Wydawniczy.

Tomasello, M. 2005. Constructing a Language: A Usage-Based Theory of Language Acquisition. Cambridge: Harvard University Press.

Tomasello, M. Carpenter, M. Call, J. 2007. Rozumienie i wspólnota intencji jako źródła kulturowego poznawania. VIA COMMUNICANDI Wspólnota komunikacyjna $w$ teorii i praktyce, Sierocka, B. (red.). Wrocław: Oficyna Wydawnicza ATUT.

Walencik-Topiłko, A. 2005. Wykorzystanie programów komputerowych w profilaktyce, diagnozie i terapii logopedycznej. w Podstawy Neurologopedii, Gałkowski, T., E., S. i Jastrzębowska, G. (red.). Opole: Wydawnictwo Uniwersytetu Opolskiego. 10191027.

Wilczyńska, W. 1999. Uczyć się czy być nauczanym. O autonomii w przyswajaniu języka obcego. Warszawa: Wydawnictwo Naukowe PWN.

Wise, B., J. Ring, i R. Olson. 2000. Individual Differences in Gains form Computer-Assisted Remedial Reading. Journal of Experimental Child Psychology 77:197-235.

Wise, B., R. Cole, S. van Vuuren, S. Schwartz, L. Snyder, N. Ngampatipatpong, J. Tuantranont, i B. Pellom. [w druku]. Learning to Read with a Virtual Tutor: Foundations Literacy. w Interactive Literacy Education. (red.). Mahwah, NJ: Lawrence Erlbaum. http://CSLR.colorado.edu/beginweb/virtual_tutor/virtual_tutor.html

Wygotski, L. 1989. Myślenie i mowa. Warszawa: Państwowe Wydawnictwa Naukowe. 